\title{
A mathematical approach to human pterygium shape
}

\author{
This article was published in the following Dove Press journal: \\ Clinical Ophthalmology \\ 22 July 2016 \\ Number of times this article has been viewed
}

\author{
Bojan Pajic ${ }^{1-4}$ \\ Iraklis Vastardis' \\ Predrag Rajkovic ${ }^{5}$ \\ Brigitte Pajic-Eggspuehler' \\ Daniel M Aebersold ${ }^{6}$ \\ Zeljka Cvejic ${ }^{2}$ \\ 'Eye Clinic ORASIS, Swiss Eye \\ Research Foundation, Reinach AG, \\ Switzerland; ${ }^{2}$ Department of Physics, \\ Faculty of Sciences, University of Novi \\ Sad, Novi Sad, ${ }^{3}$ Faculty of Medicine \\ of the Military Medical Academy, \\ University of Defence, Belgrade, \\ Serbia; ${ }^{4}$ Division of Ophthalmology, \\ Department of Clinical \\ Neurosciences, Geneva University \\ Hospitals, Geneva, Switzerland; \\ ${ }^{5}$ Department of Mathematics, Faculty \\ of Mechanical Engineering, University \\ of Niš, Niš, Serbia; ${ }^{6}$ Department of \\ Radiation Oncology, Inselspital, Bern \\ University Hospital, Bern, Switzerland
}

Correspondence: Bojan Pajic

Swiss Eye Research Foundation,

Eye Clinic ORASIS, Titlisstrasse 44,

5734 Reinach, Switzerland

Tel +4I 627656080

Email bpajic@datacomm.ch
Purpose: Pterygium is a common lesion affecting the population in countries with high levels of ultraviolet exposure. The final shape of a pterygium is the result of a growth pattern, which remains poorly understood. This manuscript provides a mathematical analysis as a tool to determine the shape of human pterygia.

Materials and methods: Eighteen patients, all affected by nasal unilateral pterygia, were randomly selected from our patient database independently of sex, origin, or race. We included all primary or recurrent pterygia with signs of proliferation, dry eye, and induction of astigmatism. Pseudopterygia were excluded from this study. Pterygia were outlined and analyzed mathematically using a Cartesian coordinate system with two axes (X, Y) and five accurate landmarks of the pterygium.

Results: In 13 patients ( $72 \%$ ), the shape of the pterygia was hyperbolic and in five patients (28\%), the shape was rather elliptical.

Conclusion: This analysis gives a highly accurate mathematical description of the shape of human pterygia. This might help to better assess the clinical results and outcome of the great variety of therapeutic approaches concerning these lesions.

Keywords: etiology, pterygium, limbal stem cells, stem cells dysfunction, mathematical shape analysis

\section{Introduction}

The medical term "pterygium" is derived from the Greek word "pteron", meaning wing. Pterygia are common and frequently recurring ocular surface lesions, affecting predominately the population in warm climate countries near the equator, the Mediterranean, and the Asia Minor, where exposure to ultraviolet (UV) light is more prominent. ${ }^{1,2}$ Clinically, a pterygium is a bulking, vascular tissue, which expands toward the center of the cornea. Pterygia may originate from the corneal limbus, where the limbal epithelial stem cells are proliferating, using the Bowman's membrane as a leading structure, destroying the latter and the epithelium during their advancement. ${ }^{3,4}$

In a normal ocular surface, the corneal epithelium has a thickness of $\sim 50 \mu \mathrm{m}$ and consists of up to five to seven layers of regularly arranged, nonkeratinized, squamous epithelial cells..$^{5-8}$ The limbus represents a zone of transition of ten to twelve layers of epithelial cells containing melanocytes, Langerhans cells, and a network of blood vessels, the latter serving as repositories of corneal epithelial cells, which then would respond in replacing defective corneal epithelium in cases of corneal melting, recurrent erosion, or chemical burns. The limbal stroma is arranged in radial fibrovascular elevations, termed the palisades of Vogt. These are predominantly found in the upper and lower corneoscleral limbus, where the vessels seem to originate. ${ }^{9,10}$ No goblet cells are present in the limbal stroma. The bulbar conjunctiva consists of six to nine layers of epithelial cells. These cells are not as regularly and compactly arranged as in the cornea. They are also smaller 
and show wide intercellular spaces. The presence of secreting goblet cells is characteristic for the conjunctival epithelium; goblet cells comprise $7 \%$ of the basal cell population. ${ }^{11}$

In normal conditions, the corneal epithelium renews every 7 to 10 days, ${ }^{12}$ mimicking a state of constant healing; squamous epithelial cells are continuously shed into the tear pool and replaced by fresh migrating cells moving centrally from the limbal area. This theory was first assumed by Thoft and Friend in his X, Y, Z hypothesis, ${ }^{13}$ where he declared that if the corneal epithelium is to be maintained, cell loss must be balanced by cell replacement $(X+Y=Z$, where $X$ stands for the proliferation of basal epithelial cells, $\mathrm{Y}$ stands for the contribution to the cell mass by centripetal movement of peripheral cells, and $\mathrm{Z}$ stands for the epithelial cell loss from the surface). This hypothesis gave birth to a multitude of studies on the location of stem cells, their centripetal migration to the cornea, and the healing pattern of the cornea under normal and pathological conditions. Cumulative evidence has clearly established the limbal basal epithelium as one of the repositories of stem cells for corneal epithelial cells. ${ }^{11,14,15}$ The centripetal migration and stem cells existence were established using staining materials ${ }^{16-18}$ in rabbit and mouse corneas or by identification of stem cell markers. ${ }^{19}$ In the course of corneal stem cell research, the concept of conjunctival transdifferentiation was born, ${ }^{11,20-22}$ a process in which the conjunctiva responds to corneal injury by cellular proliferation. ${ }^{20,22,23}$

Pterygia are pathological proliferative lesions of vascular inflamed tissue which affect the cornea, regarded by some as a deregulated wound healing ${ }^{4,24,25}$ and by others as a degenerative disease. ${ }^{25,26}$ A number of studies regarding pathogenesis, histology, and surgical treatment of these lesions have been performed in the past years. However, no study focusing on the shape of pterygia has been published.

We believe that the shape of these lesions may help support the hypothesis that the pterygium is a consequence of limbal stem cell deficiency or malfunction and the centripetal movement of the corneal cells.

\section{Materials and methods}

Eighteen patients (12 females) with a median age of $59 \pm 9.6$ years and unilateral pterygium were recruited in a single center (ORASIS Eye Clinic, Reinach AG, Switzerland). Sixteen pterygia were primary and two recurrent, with sizes varying from 1.2 to $4.0 \mathrm{~mm}$ (mean $2.51 \pm 0.83 \mathrm{~mm}$ ) and from 2.2 to $2.4 \mathrm{~mm}$ (mean $2.3 \pm 0.14 \mathrm{~mm}$ ), respectively. Thirteen patients $(72 \%)$ were of Swiss origin and had lived their entire life in Switzerland, and five patients (28\%) were of Mediterranean origin and had grown up in their home countries. The research adhered to the tenets of the
Declaration of Helsinki. According to the ethics committee of Ethikkommission Nordwest- und Zentralschweiz (EKNZ) as this is a mathematical model with anonymous pterygium data, ethics approval and patient consent is not required.

Pictures of each pterygium were taken at the initial ophthalmological examination using a camera (FF 450/FF 450 IR; Carl Zeiss Meditec AG, Jena, Germany) and analyzed. Slit lamp measurements of each pterygium's length, size, and distance of the head to the corneal limbus were made in order to control the digital measurements. Corneal topography was performed using a video keratoscope (Orbscan II version 3.0, Bausch \& Lomb Zyoptix; Bausch \& Lomb Incorporated, Bridgewater, NJ, USA) which served to determine corneal astigmatism and white-to-white distance. All digitized pictures were magnified and the pterygium was outlined using AutoCAD ${ }^{\circledR}$ V 04 (Autodesk Inc., San Rafael, CA, USA). Later on, the same program was used to assess the various topographical values (diameter and digital outline of the pterygium). The goal was to generate a high-precision digital photo of every pterygium in a Cartesian coordinate system, using two axes $(\mathrm{X}, \mathrm{Y})$ and five accurate geographical points on the pterygium, in the same scale $(\mathrm{mm})$ as in corneal topography. Point (F) is always passing through the intersection of the two axes $\mathrm{F}(0,0)$ in order to have a landmark and a standard procedure in calculating the measurements and to reassure the integrity of results (Figure 1). The eye is a sphere, but if we consider that corneal topography represents the eye rather as a vertical dissection of the sphere, then the pterygium is simply a protrusion in the eye's cutting plane.

\section{Results}

We examined the pictures of each pterygium taken at the initial ophthalmological examination using a camera. On the contour plane curves which were seen, we measured the coordinates of

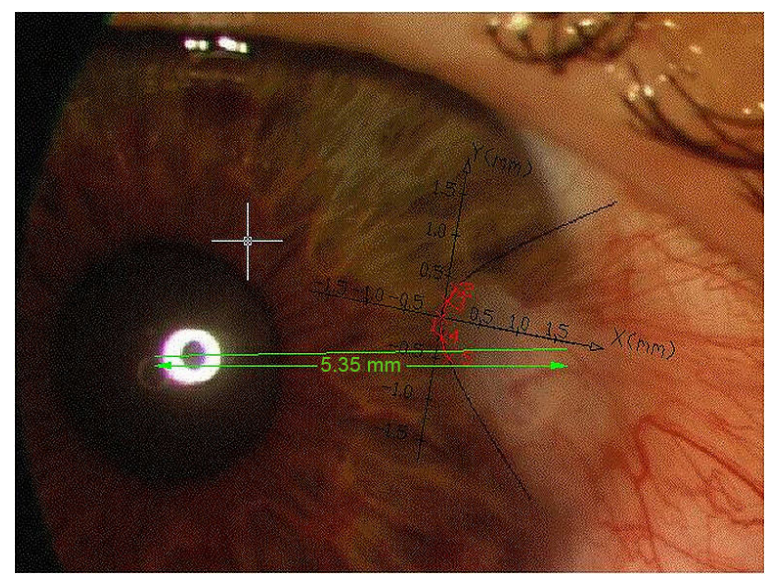

Figure I Point $(F)$ is always passing through the intersection of the two axes $F(0,0)$ in order to have a landmark. 
Table I Coordinates of the five accurate points for all accounted pterygia

\begin{tabular}{|c|c|c|c|c|c|c|c|c|c|c|c|}
\hline $\begin{array}{l}\text { Five } \\
\text { points }\end{array}$ & $X$-axis & $Y$-axis & $\begin{array}{l}\text { Five } \\
\text { points }\end{array}$ & $X$-axis & $Y$-axis & $\begin{array}{l}\text { Five } \\
\text { points }\end{array}$ & $X$-axis & Y-axis & $\begin{array}{l}\text { Five } \\
\text { points }\end{array}$ & $X$-axis & $Y$-axis \\
\hline Pat I & $X(\mathrm{~mm})$ & $\mathbf{Y}(\mathrm{mm})$ & Pat 2 & $X(\mathrm{~mm})$ & $\mathbf{Y}(\mathrm{mm})$ & Pat 3 & $X(\mathrm{~mm})$ & $Y(\mathbf{m m})$ & Pat 4 & $X(\mathrm{~mm})$ & $\mathbf{Y}(\mathrm{mm})$ \\
\hline I & 0 & 0 & I & 0 & 0 & I & 0 & 0 & I & 0 & 0 \\
\hline 2 & 0.26 & 1.14 & 2 & 0.43 & 0.95 & 2 & -0.58 & 1.16 & 2 & -0.38 & 0.87 \\
\hline 3 & 0.15 & 0.81 & 3 & 0.09 & 0.45 & 3 & -0.2 & 0.62 & 3 & -0.06 & 0.37 \\
\hline 4 & 0.19 & -0.87 & 4 & 0.12 & -0.54 & 4 & -0.22 & -0.62 & 4 & -0.06 & -0.36 \\
\hline \multirow[t]{2}{*}{5} & 0.47 & -1.56 & 5 & 0.4 & -0.92 & 5 & -0.47 & -0.99 & 5 & -0.5 & -0.98 \\
\hline & Hyperbole & & & Ellipse & & & Hyperbole & & & Ellipse & \\
\hline Pat 5 & $X(\mathrm{~mm})$ & $\mathbf{Y}(\mathrm{mm})$ & Pat 6 & $X(\mathrm{~mm})$ & $\mathbf{Y}(\mathbf{m m})$ & Pat 7 & $X(\mathrm{~mm})$ & $\mathbf{Y}(\mathbf{m m})$ & Pat 8 & $X(\mathrm{~mm})$ & $\mathbf{Y}(\mathrm{mm})$ \\
\hline I & 0 & 0 & 1 & 0 & 0 & I & 0 & 0 & 1 & 0 & 0 \\
\hline 2 & -0.75 & 2.4 & 2 & -0.57 & 0.95 & 2 & 0.14 & 0.38 & 2 & 0.68 & 1.85 \\
\hline 3 & -0.38 & 1.53 & 3 & -0.19 & 0.51 & 3 & 0.06 & 0.19 & 3 & 0.26 & 1.15 \\
\hline 4 & $-0.4 \mathrm{I}$ & -1.49 & 4 & -0.13 & -0.52 & 4 & 0.15 & -0.44 & 4 & 0.06 & -0.54 \\
\hline \multirow[t]{2}{*}{5} & -0.92 & -2.45 & 5 & -0.31 & -0.86 & 5 & 0.28 & -0.62 & 5 & 0.45 & -1.57 \\
\hline & Hyperbole & & & Hyperbole & & & Hyperbole & & & Hyperbole & \\
\hline Pat 9 & $X(\mathrm{~mm})$ & $\mathbf{Y}(\mathrm{mm})$ & Pat 10 & $X(\mathrm{~mm})$ & $\mathbf{Y}(\mathrm{mm})$ & Pat II & $X(\mathrm{~mm})$ & $Y(\mathbf{m m})$ & Pat I2 & $X(\mathrm{~mm})$ & $Y(\mathrm{~mm})$ \\
\hline I & 0 & 0 & I & 0 & 0 & I & 0 & 0 & 1 & 0 & 0 \\
\hline 2 & 0.31 & 0.8 & 2 & -1.05 & 1.58 & 2 & -0.23 & 0.88 & 2 & -0.36 & 0.61 \\
\hline 3 & 0.13 & 0.56 & 3 & -0.61 & 1.15 & 3 & -0.11 & 0.61 & 3 & -0.07 & 0.26 \\
\hline 4 & 0.06 & -0.32 & 4 & -0.18 & -0.57 & 4 & -0.04 & -0.42 & 4 & -0.3 & -0.56 \\
\hline \multirow[t]{2}{*}{5} & 0.15 & -0.5 & 5 & -0.6 & -1.09 & 5 & -0.22 & -0.88 & 5 & -0.56 & -0.8 \\
\hline & Ellipse & & & Hyperbole & & & Ellipse & & & Hyperbole & \\
\hline Pat I3 & $X(\mathrm{~mm})$ & $\mathbf{Y}(\mathbf{m m})$ & Pat 14 & $X(\mathrm{~mm})$ & $\mathbf{Y}(\mathbf{m m})$ & Pat I5 & $X(\mathrm{~mm})$ & $\mathbf{Y}(\mathbf{m m})$ & Pat 16 & $X(\mathrm{~mm})$ & $\mathbf{Y}(\mathbf{m m})$ \\
\hline I & 0 & 0 & 1 & 0 & 0 & I & 0 & 0 & I & 0 & 0 \\
\hline 2 & -0.48 & 0.98 & 2 & 0.22 & 0.66 & 2 & -0.4 & 0.99 & 2 & 0.36 & 1.06 \\
\hline 3 & -0.1 & 0.45 & 3 & 0.07 & 0.39 & 3 & -0.19 & 0.67 & 3 & 0.08 & 0.48 \\
\hline 4 & -0.32 & -0.74 & 4 & 0.12 & -0.49 & 4 & -0.05 & -0.33 & 4 & 0.15 & -0.73 \\
\hline \multirow[t]{2}{*}{5} & -0.74 & -1.21 & 5 & 0.23 & -0.66 & 5 & -0.2 & -0.67 & 5 & 0.26 & -0.96 \\
\hline & Hyperbole & & & Ellipse & & & Hyperbole & & & Hyperbole & \\
\hline Pat 17 & $X(\mathrm{~mm})$ & $\mathbf{Y}(\mathrm{mm})$ & Pat 18 & $X(\mathrm{~mm})$ & $\mathbf{Y}(\mathbf{m m})$ & & & & & & \\
\hline I & 0 & 0 & 1 & 0 & 0 & & & & & & \\
\hline 2 & 0.63 & 0.97 & 2 & $0.5 \mathrm{I}$ & 1.07 & & & & & & \\
\hline 3 & 0.32 & 0.66 & 3 & 0.21 & 0.65 & & & & & & \\
\hline 4 & 0.15 & -0.44 & 4 & 0.27 & -0.77 & & & & & & \\
\hline \multirow[t]{2}{*}{5} & $0.4 I$ & -0.79 & 5 & 0.55 & -1.18 & & & & & & \\
\hline & Hyperbole & & & Hyperbole & & & & & & & \\
\hline
\end{tabular}

Abbreviation: Pat, patient.

five points (Table 1). For some patients, a few points were too close to enable us to estimate curve's type. Hence, we used the software to determine four more points on the contour curve.

We applied the spline approximations through those nine points which successfully reconstructed the curve. Reconstructed graphs of contour curve by spline approximation are shown in Figure 2. Since the original curves were very similar to conics, we took five points: the first is the point which is the nearest to the origin of supposed conic; a further two points distinguished from one side and two from the other side. The most simple class of curves which pass through five plane points is the class of conic sections which satisfies the equation of the form (Figure 3):

$$
\begin{aligned}
& \text { Point } \mathrm{X} Y \\
& \begin{array}{llll}
1 & x_{1} & y_{1}
\end{array} \\
& \begin{array}{lll}
2 & x_{2} & y_{2}
\end{array} \\
& \begin{array}{lll}
3 & x_{3} & y_{3}
\end{array} \\
& \begin{array}{lll}
4 & x_{4} & y_{4}
\end{array} \\
& \begin{array}{llll}
5 & x_{5} & y_{5}
\end{array} \\
& \operatorname{det}(M)=\left|\begin{array}{cccccc}
x^{2} & x y & y^{2} & x & y & 1 \\
x_{1}^{2} & x_{1} y_{1} & y_{1}^{2} & x_{1} & y_{1} & 1 \\
x_{2}^{2} & x_{2} y_{2} & y_{2}^{2} & x_{2} & y_{2} & 1 \\
x_{3}^{2} & x_{3} y_{3} & y_{3}^{2} & x_{3} & y_{3} & 1 \\
x_{4}^{2} & x_{4} y_{4} & y_{4}^{2} & x_{4} & y_{4} & 1 \\
x_{5}^{2} & x_{5} y_{5} & y_{5}^{2} & x_{5} & y_{5} & 1
\end{array}\right|=0 .
\end{aligned}
$$

The previous equation given by the determinant can be written in the form $A x^{2}+2 B x y+C y^{2}+2 D x+$ $2 E y+F=0$. 
Denote

$$
s=A+C, \quad \delta=\left|\begin{array}{ll}
A & B \\
B & C
\end{array}\right|=-\left(B^{2}-A C\right), \quad \Delta=\left|\begin{array}{ccc}
A & B & D \\
B & C & E \\
D & E & F
\end{array}\right|
$$

According to the analytical geometry, this equation determines:

1. Ellipse if $\delta>0 \wedge s \Delta<0$

2. Hyperbola if $\delta<0 \wedge \Delta \neq 0$

3. Parabola if $\delta=0 \wedge \Delta \neq 0$

By plotting original curve, spline, and conics, we obtained very close graphs for every patient (Table 2). So, we can conclude that the shape of pterygia is of conic form.

Equations of conics for five patients were calculated (Table 3). These equations show that the conics are slightly rotated around $\mathrm{X}$-axis; therefore, the graphs are not symmetrically located by X-axis (Figure 4).

\section{Discussion}

A multitude of clinical studies have been published on pterygia over the years. The description of the pterygium shape has

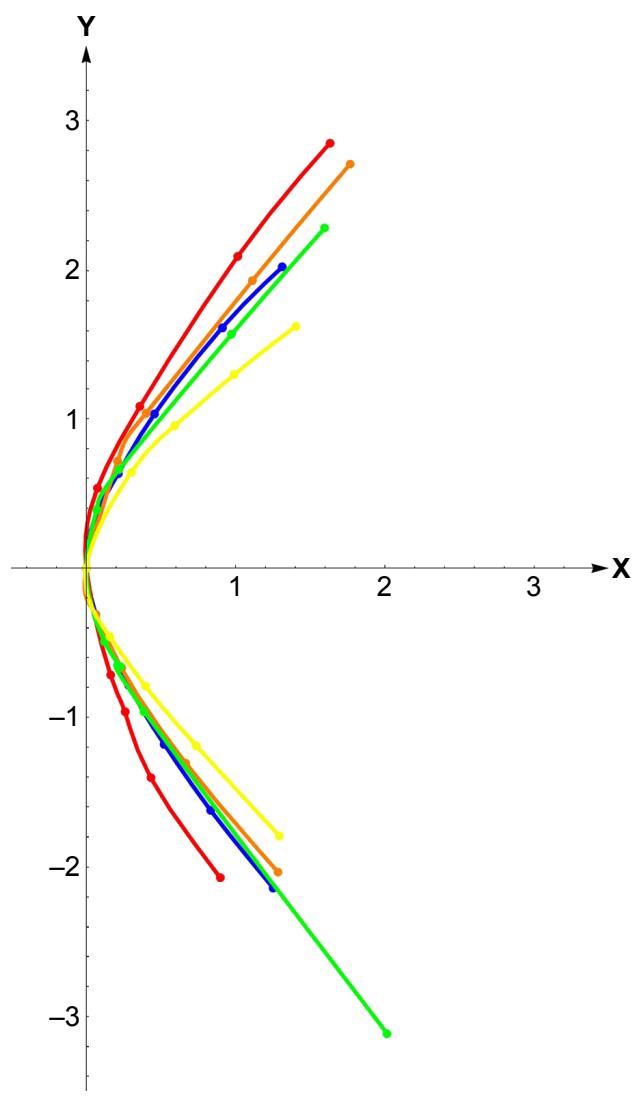

Figure 2 Spline approximations.

Note: The different colors represent 5 different Pterygium shapes.

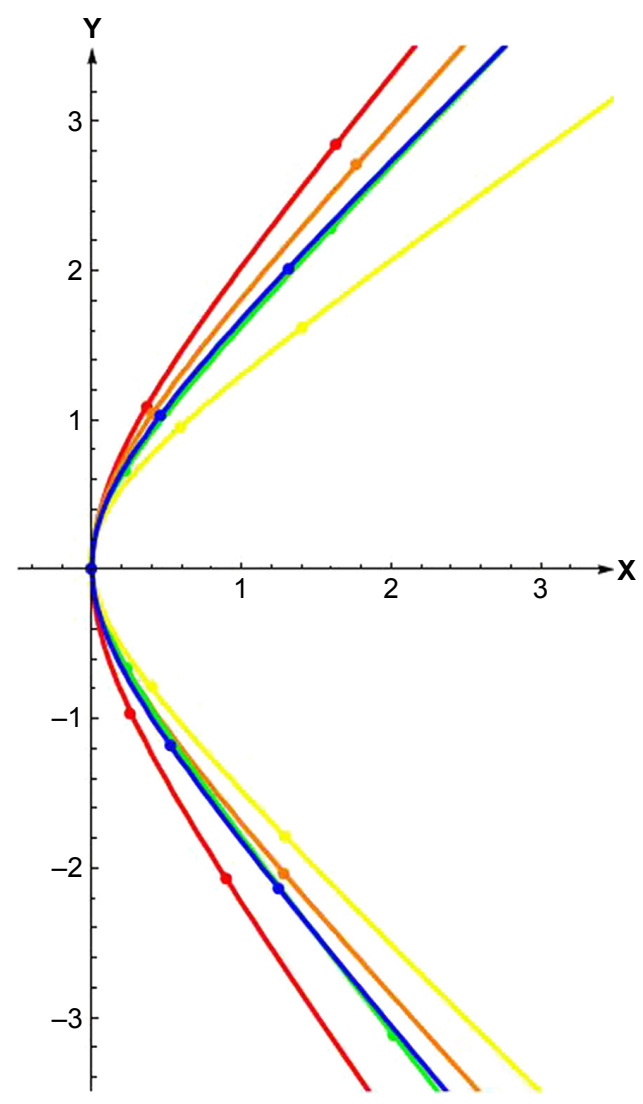

Figure 3 Conics.

Note: The different colors represent 5 different Pterygium shapes.

always been vague, referring to it as a triangular, bulky, or windy-shaped lesion. We decided to determine the shape of these lesions and found a conic shape in all the pterygia examined.

The pathogenesis of pterygium is complex. Its incidence and prevalence vary according to the geographical region, favoring regions with high exposure to UV radiation (290-400 nm). ${ }^{1,2}$ Dushku and Reid ${ }^{27}$ first showed that mutations in the TP53 gene expressed in the parental limbal basal cells following UV light exposure may be responsible for the production of abnormal elastotic material and for the invasion of the cornea with various MMPs, resulting in the excessive production of transforming growth factor-beta (TGF- $\beta$ ) via the p53-RbTGF- $\beta$ pathway. ${ }^{4}$ Fibroblast growth factors, vascular endothelial growth factors responsible for angiogenesis, and stem cell factors are also upregulated., ${ }^{4,28}$ Girolamo et $\mathrm{al}^{29}$ reported the abundant expression of MMP-1 in pterygium tissue and only recently reinforced his study when he postulated that MMP-1 is a likely candidate enzyme for pterygium formation, because UV light regulates this enzyme at the level of transcription and translation, establishing a direct link between UV exposure and the induction of matrix-denaturing enzymes in pterygia. ${ }^{30}$

In normal conditions, the corneal epithelium is constantly renewed every 7 to 10 days. ${ }^{12}$ This condition was 
Table 2 Equations of all 18 pterygia

\begin{tabular}{|c|c|c|}
\hline Patient no & Function & Equation \\
\hline Patient I & Hyperbole & $0.04076 x^{2}-0.00828 y^{2}+0.00236 x y+0.02772 x+0.00009 y=0$ \\
\hline Patient 2 & Ellipse & $0.00599 x^{2}+0.00757 y^{2}-0.00056 x y-0.01841 x+0.00022 y=0$ \\
\hline Patient 3 & Hyperbole & $0.03320 x^{2}-0.02767 y^{2}-0.00076 x y+0.04364 x+0.00109 y=0$ \\
\hline Patient 4 & Ellipse & $0.00351 x^{2}+0.00498 y^{2}+0.00017 x y-0.01126 x-0.00006 y=0$ \\
\hline Patient 5 & Hyperbole & $2.76910 x^{2}-0.91154 y^{2}+0.37047 x y+4.18353 x-0.04651 y=0$ \\
\hline Patient 6 & Hyperbole & $0.00923 x^{2}-0.00894 y^{2}-0.00443 x y+0.01370 x-0.00035 y=0$ \\
\hline Patient 7 & Hyperbole & $0.00029 x^{2}-0.00011 y^{2}+0.00009 x y+0.00009 x-0.00002 y=0$ \\
\hline Patient 8 & Hyperbole & $0.02800 x^{2}-0.06723 y^{2}-0.01546 x y+0.34070 x+0.00266 y=0$ \\
\hline Patient 9 & Ellipse & $0.00054 x^{2}+0.00035 y^{2}-0.00007 x y-0.00077 x-0.00002 y=0$ \\
\hline Patient 10 & Hyperbole & $0.09636 x^{2}-0.22137 y^{2}+0.01235 x y+0.40036 x+0.00350 y=0$ \\
\hline Patient II & Ellipse & $0.00104 x^{2}+0.00061 y^{2}-0.00015 x y-0.00232 x+0.00004 y=0$ \\
\hline Patient 12 & Hyperbole & $0.00187 x^{2}-0.00574 y^{2}-0.00025 x y+0.00536 x+0.00003 y=0$ \\
\hline Patient 13 & Hyperbole & $0.02159 x^{2}-0.04652 y^{2}-0.00245 x y+0.07845 x+0.00327 y=0$ \\
\hline Patient 14 & Ellipse & $0.00044 x^{2}+0.00040 y^{2}-1.93446 \times 10^{-6} x y-0.00087 x-4.66188 \times 10^{-6} y=0$ \\
\hline Patient 15 & Hyperbole & $0.00057 x^{2}-0.00148 y^{2}+0.00007 x y+0.00331 x+0.00001 y=0$ \\
\hline Patient 16 & Hyperbole & $0.00095 x^{2}-0.00247 y^{2}-0.00013 x y+0.00788 x-0.00013 y=0$ \\
\hline Patient 17 & Hyperbole & $0.01067 x^{2}-0.01755 y^{2}-0.00246 x y+0.02122 x+0.00043 y=0$ \\
\hline Patient 18 & Hyperbole & $0.03332 x^{2}-0.03374 y^{2}-0.00432 x y+0.06269 x+0.00032 y=0$ \\
\hline
\end{tabular}

supported by Thoft and Friend in his X, Y, Z hypothesis, ${ }^{13}$ when he declared that if the corneal epithelium is to be maintained, cell loss must be balanced by cell replacement. These cells were initially assumed to migrate with centripetal movements from the periphery to the center of the cornea in cases of corneal damage tissue. Later, it was proved by Pellegrini et $\mathrm{al}^{31}$ that the stem cell population appears to be localized to the palisades of Vogt in the limbal region. ${ }^{9,10}$

Thoft and Friend ${ }^{13}$ initially stated that "while the movement of the cells from the periphery of the cornea seems well established, the source of these cells were uncertain". Later, they restated that the original, X, Y, Z hypothesis did not ascribe an origin of these cells, ${ }^{32}$ assuming that conjunctiva could simply drift across the limbus to provide either acute or chronic replacement of peripheral cells through a process called conjunctival transdifferentiation. Various studies in mice and rabbits have shown that the conjunctival cells can also migrate to the cornea after denudation of the corneal epithelium, ${ }^{11,20,22}$ resulting in vascularization of the cornea if the limbus is removed. Under normal circumstances, the limbal epithelium acts as a barrier and is able to exert an

Table 3 Equations of conics for five patients

\begin{tabular}{ll}
\hline Patient & Equations of hyperbolas \\
\hline 16 & $-4.8924 x^{2}+0.5976 x y+3.0387 y^{2}-8.8581 x+0.0280 y=0$ \\
17 & $-5.9591 x^{2}-0.0285 x y+5.2167 y^{2}-10.1380 x-0.5713 y=0$ \\
18 & $-8.8767 x^{2}+1.6141 x y+6.9860 y^{2}-11.5030 x-0.4806 y=0$ \\
12 & $-1.8938 x^{2}+0.7338 x y+2.8284 y^{2}-3.5674 x-0.2207 y=0$ \\
15 & $-4.0144 x^{2}+0.6306 x y+3.5808 y^{2}-6.9281 x-0.1073 y=0$ \\
\hline
\end{tabular}

inhibitory growth pressure preventing migration of conjunctival epithelial cells onto the cornea. ${ }^{33}$

Shapiro et $\mathrm{al}^{23}$ divided this process into five stages, depending on the presence and density of goblet cells and the degree of stratification of the conjunctival epithelium. The overall process has been extensively studied and the current hypothesis concludes that goblet cells do not migrate onto the cornea but rather develop de novo from non-goblet epithelial cells. ${ }^{34}$ Vascularization of the regenerated epithelium is associated with poor transdifferentiation and persistence of goblet cells. ${ }^{35}$ In a recent study, it was concluded that the cytology of surface cells in pterygium exhibits squamous metaplasia with increased goblet cell density and that a graded series of ocular surface changes exists throughout the bulbar conjunctiva (even the unaffected one) in eyes with pterygium, with the most advanced changes occurring directly over the pterygium surface. ${ }^{36}$ In vivo confocal

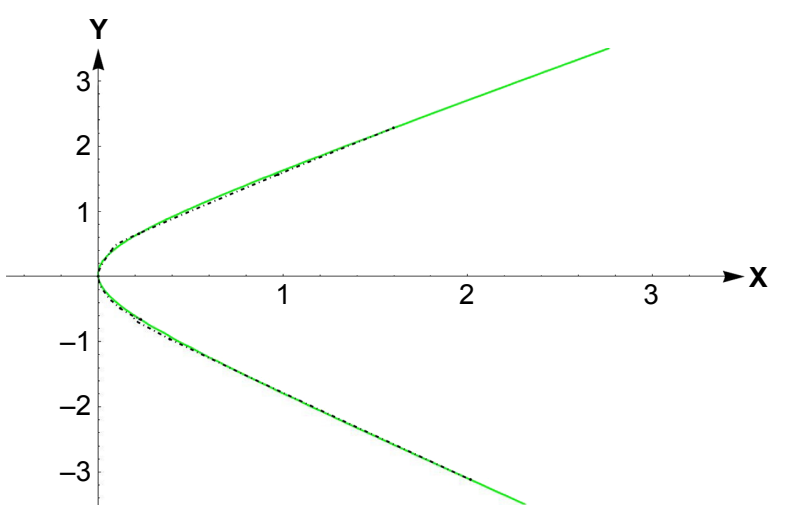

Figure 4 Overlapping of spline approximation and conics in the case of patient 18. 
analysis of pterygium showed that conjunctival epithelial cells were also recognizable on the head of the lesion. ${ }^{37}$

Despite the multitude of recent studies, the exact shape of pterygia was not investigated. One of the rare attempts to characterize the growth pattern and shape observed in pterygia was given by Chui et al. ${ }^{38}$ They assumed that the direction of epithelial cell movements follows the radial curve of nerves. Furthermore, they detected a neuropeptide $\mathrm{K}\left(\mathrm{NK}_{1}\right)$ receptor and a sensory neuropeptide substance $\mathrm{P}$ in pterygia. The latter is a potent chemoattractant for pterygium fibroblasts and vascular endothelial cells, implying that substance $\mathrm{P}$, given the radial pattern of the corneal innervation, may contribute to determine the shape of pterygia.

According to our mathematical calculations, all pterygia examined were of conic shape. Regarding other theories that reinforced the centripetal movements of stem cells and according to the data of the various publications regarding the pterygium pathogenesis mentioned earlier, we could conclude that the conjunctival epithelium is allowed to intrude the cornea, forming the pterygium with the known cytology. ${ }^{36,37}$ This centripetal movement of cells has been confirmed in animal models. ${ }^{39,40}$

If the centripetal movement is indeed the result of reactive forces and a result of centripetal force acting on these cells, with the principle that any matter would obey the laws of physics, then when this matter is inserted in that field, which is itself a convention designed around particular forces, then that body must obey the laws associated with that field. This is supported by studies where limbal transplant surgery results in healing with corneal epithelium. ${ }^{41,42}$ Conversely, in animal models, surgical removal of the limbus leads to healing with noncorneal epithelium. ${ }^{21}$

Nevertheless, we feel that this mathematical analysis of pterygium shape may represent a significant piece in the puzzle representing the pathogenesis of pterygia, proving that pterygia repeatedly adapt to same shape and form, in this case a conic shape.

\section{Acknowledgment}

Parts of our original work were presented in the poster session during the XXXIII Congress of the ESCRS, 5-9 September, 2015, in Barcelona, Spain.

\section{Disclosure}

The authors report no conflicts of interest in this work.

\section{References}

1. Coroneo MT. Pterygium as an early indicator of ultraviolet insolation: a hypothesis. Br J Ophthalmol. 1993;77:734-739.
2. Coroneo MT, Girolamo ND, Wakefield D. The pathogenesis of pterygia. Curr Opin Ophthalmol. 1999;10:282-288.

3. Dushku N, Reid TW. Immunohistochemical evidence that human pterygia originate from an invasion of vimentin-expressing altered limbal epithelial basal cells. Curr Eye Res. 1994;13:473-481.

4. Dushku N, Molykutty KJ, Schultz GS, Reid TW. Pterygia pathogenesis: corneal pathogenesis by matrix metalloproteinase expressing altered limbal epithelial basal cells. Arch Ophthalmol. 2001;119: 695-701.

5. Arffa RC. Diseases of the cornea. In: Grayson's Diseases of the Cornea. 3rd ed., Anatomy. St Louis: Mosby; 1991.

6. Friend J. Physiology of the cornea. In: Smolin G, Thoft RA, editors. The Cornea Scientific Foundations and Clinical Practice. 2nd ed. Boston: Little Brown \& Co; 1987.

7. Kenyon KR. Anatomy and pathology of the ocular surface. In: Thoft RA, Friend JR, editors. International Ophthalmology Clinics. Vol 19. The Ocular Surface. Boston: Little Brown \& Co; 1979.

8. Maudgal PC, Missotten L, editors. Monographs in Ophthalmology 1. Superficial Keratitis. The Hague: Dr. W. Junk Publishers; 1980.

9. Goldberg MF, Bron AJ. Limbal palisades of Vogt. Trans Am Ophthalmol Soc. 1982;80:155-171.

10. Townsend WM. The limbal palisades of Vogt. Trans Am Ophthalmol Soc. 1991;89:721-756.

11. Dua HS, Gomes JAP, Singh A. Corneal epithelial wound healing. Br J Ophthalmol. 1994;78:401-408.

12. Hanna C, O'Brien JE. Cell production and migration of corneal epithelial maintenance. Invest Ophthalmol Vis Sci. 1983;24:1442-1443.

13. Thoft RA, Friend J. The X, Y, Z hypothesis of corneal epithelial maintenance. Invest Ophthalmol Vis Sci. 1983;24:1442-1443.

14. Lavker RM, Tseng SCG, Sun TT. Corneal epithelial stem cells at the limbus: looking at some old problems from a new angle. Exp Eye Res. 2004;78:433-466.

15. O'Sullivan F, Clynes M. Limbal stem cells, a review of their identification and culture for clinical use. Cytotechnology. 2007;53:101-106.

16. Buck RC. Measurement of Centripetal migration of normal corneal epithelial cells in mouse. Invest Ophthalmol Vis Sci. 1985;26(9): 1296-1299.

17. Keller RE. Vital dye mapping of gastrula and neurula of Xenopus Leavis. II. Prospective areas and morphogenic movements in the deep layer. Dev Biol. 1976;51:118-137.

18. Spratt NT. Localization of the prospective neural plate in the early chick blastoderm. J Exp Zool. 1952;120:109-130.

19. Zieske JD, Bukusoglu G, Yankauckas MA. Characterization of a potential marker of corneal epithelial stem cells. Invest Ophthalmol Vis Sci. 1992;33(1):143-152.

20. Danjo S, Friend J, Thoft RA. Conjunctival epithelium in healing of corneal epithelial wounds. Invest Ophthalmol Vis Sci. 1987;28(9):1445-1449.

21. Huang AJW, Tseng SCG. Corneal epithelium wound healing in the absence of limbal epithelium. Invest Ophthalmol Vis Sci. 1991;32(1): 96-105.

22. Kruse FE, Chen JJY, Tsai RJF, Tseng SCG. Conjunctival transdifferentiation is due to the incomplete removal of limbal basal epithelium. Invest Ophthalmol Vis Sci. 1990;31(9):1903-1913.

23. Shapiro MS, Friend J, Thoft RA. Corneal re-epithelialization from the conjunctiva. Invest Ophthalmol Vis Sci. 1981;21(1):135-142.

24. Tan DTH, Lim ASH, Goh HS, Smith DR. Abnormal expression of the P53 tumor suppressor gene in the conjunctiva of patients with pterygium. Am J Ophthalmol. 1997;123:404-405.

25. Wang IJ, Hu FR, Chen PJ, Lin CT. Mechanism of abnormal elastin gene expression in the pinguecular part of pterygia. Am J Ophthalmol. 2000;157:1269-1276.

26. Austin P, Jakobiec FA, Iwamoto T. Elastodyplasia and elastodystrophy as the pathologic bases of ocular pterygia and pinguecula. Ophthalmology. 1983;90:96-109.

27. Dushku N, Reid TW. P53 expression in altered limbal basal cells of pingueculae, pterygia and limbal tumors. Curr Eye Res. 1997;16: 1179-1192. 
28. Kria L, Ohira A, Ameniya T. Immunohistochemical localization of basic fibroblast growth factor, platelet derived growth factor, transforming growth factor-beta, and tumor necrosis factor-alpha in the pterygium. Acta Histochem. 1996;98:195-201.

29. Girolamo ND, McCluskey P, Lloyd A, Coroneo MT, Wakefield D. Expression of MMPs and TIMPs in human pterygia and cultured pterygium epithelial cells. Invest Ophthalmol Vis Sci. 2000;41:671-679.

30. Girolamo ND, Coroneo MT, Wakefield D. UVB-elicited induction of MMP-1 expression in human ocular surface epithelial cells is mediated through the ERK1/2 MAKP-dependent pathway. Invest Ophthalmol Vis Sci. 2003;44:4705-4714.

31. Pellegrini G, Golisano O, Paterna P, et al. Location and clonal analysis of stem cells and their differentiated progeny in the human ocular surface. J Cell Biol. 1999;145:769-782.

32. Thoft RA. The role of the limbus in ocular surface maintenance and repair. Acta Ophthalmol Suppl. 1989;192:91-94.

33. Tseng SCG. Concept and application of limbal stem cells. Cell. 1989;57: 210-219.

34. Aitken D, Friend J, Thoft RA. Corneal re-epithelialization from the conjunctiva. Invest Ophthalmol Vis Sci. 1988;29:224-231.

35. Tseng SCG, Hirst LW, Farazdaghi M, Green WR. Goblet cell density and vascularization during conjuctival transdifferentiation. Invest Ophthalmol Vis Sci. 1984;25:1168-1176.
36. Chan CML, Tan DTH. Ocular surface changes in pterygium. Cornea. 2002;21(1):38-42.

37. Gheck L, Dupas B, Denion E, Amar N, Baudoin C. Apport de la microscopie confocale in vivo à l'étude des pterygions [Contribution of confocal microscopy in vivo study of pterygium]. J Fr Ophthalmol. 2007;30(7):703-710. French.

38. Chui J, Di Girolamo N, Coroneo MT, Wakefield D. The role of substance $\mathrm{P}$ in the pathogenesis of pterygium. Invest Ophthalmol Vis Sci. 2007;48(10):4482-4489.

39. Nagasaki T, Zhao J. Centripetal movement of corneal epithelial cells in normal adult mouse. Invest Ophthalmol Vis Sci. 2003;44:558-566.

40. Collinson JM, Morris L, Reid AI, et al. Clonal analysis of patterns of growth, stem cell activity, and cell movement during the development and maintenance of the murine corneal epithelium. Dev Dyn. 2002; 224:432-440.

41. Kenyon KR, Tseng SC. Corneal epithelial wound healing in the absence of limbal epithelium. Invest Ophthalmol Vis Sci. 1991;32:96-105.

42. Wang X, Chen J. Long-term efficacy and ocular surface of pterygium excision combined with autologous corneal limbal stem cell transplantation in treatment of pterygium. Eye Sci. 2015;30(3):101-105.
Clinical Ophthalmology

\section{Publish your work in this journal}

Clinical Ophthalmology is an international, peer-reviewed journa covering all subspecialties within ophthalmology. Key topics include: Optometry; Visual science; Pharmacology and drug therapy in eye diseases; Basic Sciences; Primary and Secondary eye care; Patien Safety and Quality of Care Improvements. This journal is indexed on

Submit your manuscript here: http://www.dovepress.com/clinical-ophthalmology-journal

\section{Dovepress}

PubMed Central and CAS, and is the official journal of The Society of Clinical Ophthalmology (SCO). The manuscript management system is completely online and includes a very quick and fair peer-review system, which is all easy to use. Visit http://www.dovepress.com/ testimonials.php to read real quotes from published authors. 